\title{
PENGARUH KUALITAS PRODUK TERHADAP KEPUTUSAN PEMBELIAN ULANG SABUN MANDI MEREK SHINZUI DI KOTA PALU
}

\author{
Hartati \\ Suardi \\ Ira Nuriya Santi \\ Jurusan Manajemen, Fakultas Ekonomi, Universitas Tadulako \\ Email: hartatih29m@gmail.com
}

\begin{abstract}
The purpose of this study is to determine simultaneous and partial influence of product quality both on repurchase decision of Shinzui bath soap in Palu City. Independent variables used in this study consist of performance, features, reliability, durability, conformance, aesthetics, and perceived quality; while dependent variable is repurchase decision $(Y)$. The research method is descriptive. Sample consists of 80 respondents who selected by purposive sampling technique. Data analysis method is multiple linear regressions. The result of this research shows that product quality, consists of performance, feature, reliability, durability, conformance, aesthetics, and perceived quality simultaneously have significant influence on repurchase decision of Shinzui bath soap in Palu City. Partially, product qualities that consist of feature and perceived quality have significant influence on repurchase decision of Shinzui bath soap in Palu City. While performance, reliability, durability, conformance, and aesthetics variables partially have non-significant influence on repurchase decision of Shinzui bath soap in Palu City.
\end{abstract}

Keywords: Product quality and repurchase decision.

\section{ABSTRAK}

Tujuan dari penelitian ini untuk mengetahui pengaruh kualitas produk baik secara serempak maupun parsial terhadap keputusan pembelian ulang sabun mandi Shinzui di Kota Palu. Variabel independen yang digunakan dalam penelitian ini adalah Kinerja (Performance), Keistimewaan (Features), Kehandalan (Reliability), Daya Tahan (Durability), Kesesuaian (Conformance), Estetika (Aesthetics), dan Kualitas Yang Dirasakan (Perceived Quality), sedangkan variabel dependen adalah Keputusan Pembelian Ulang (Y). Metode penelitian yang digunakan dalam penelitian ini adalah metode deskriptif. Sampel yang digunakan pada penelitian ini yaitu sebanyak 80 responden dengan bentuk pengambilan sampel menggunakan teknik purposive sampling. Metode analisis data yang digunakan dalam penelitian ini adalah metode analisis regresi linear berganda. Hasil penelitian ini menunjukkan bahwa secara simultan kualitas produk yang terdiri dari Kinerja (Performance), Keistimewaan (Features), Kehandalan (Reliability), Daya Tahan (Durability), Kesesuaian (Conformance), Estetika (Aesthetics), dan Kualitas Yang Dirasakan (Perceived Quality) berpengaruh signifikan terhadap keputusan pembelian ulang sabun mandi Shinzui di Kota Palu. Secara parsial kualitas produk yang terdiri dari Keistimewaan (Features) dan Kualitas Yang Dirasakan (Perceived Quality) berpengaruh signifikan terhadap keputusan pembelian ulang sabun mandi Shinzui di Kota Palu, Sedangkan variabel Kinerja (Performance), Kehandalan (Reliability), Daya Tahan (Durability), Kesesuaian (Conformance), dan Estetika (Aesthetics) secara parsial berpengaruh tidak signifikan terhadap keputusan pembelian ulang sabun mandi Shinzui di Kota Palu.

Kata Kunci: Kualitas produk, keputusan pembelian ulang. 


\section{PENDAHULUAN}

Keputusan pembelian seseorang tidak muncul begitu saja, akan tetapi didasari oleh dorongan terlebih dahulu. Dorongan tesebut dapat berasal dari faktor internal dan faktor eksternal. Daryanto (2014) mengungkapkan bahwa faktor yang mempengaruhi keputusan pembelian konsumen diantaranya kualitas produk. Konsumen dalam melakukan keputusan pembelian selalu mempertimbangkan hal yang berhubungan dengan kualitas dari produk yang akan dibeli. Pada saat konsumen akan mengambil suatu keputusan pembelian, variabel produk merupakan pertimbangan paling utama, karena produk adalah tujuan utama bagi konsumen untuk memenuhi kebutuhannya. Konsumen yang merasa cocok dengan suatu produk dan produk tersebut dapat memenuhi kebutuhannya, maka konsumen akan mengambil keputusan untuk membeli produk tersebut (Nabhan dan Kresnaini, 2005). Keputusan konsumen dalam penelitian ini adalah pembelian ulang produk sabun mandi Shinzui yang sama tanpa diikuti oleh perasaan yang berarti terhadap produk tersebut. Sabun mandi Shinzui merupakan salah satu brand produk dari BKP, yaitu brand produk perawatan kulit ternama di Indonesia. Shinzui dibuat dengan formulasi yang alami, dengan menggunakan minyak Herba Matsu dari Jepang. Minyak ini merupakan minyak essensial berharga yang diambil dari jamur Matsuke. Produk Shinzui bermanfaat dalam mencerahkan kulit, membuat kulit lebih lembut dan putih. Shinzui merupakan sabun kecantikan yang dibuat dari bahan alami Jepang desain dan kemasan produk sabun mandi Shinzui senantiasa dibuat lebih menarik dan inovatif agar dapat menarik para pelanggan baru serta tetap mempertahankan para pelanggan lama.

Pesaing terdekat sabun mandi Shinzui yaitu sabun mandi merek citra, selain sabun mandi Shinzui, sabun mandi citra merupakan salah satu sabun kecantikan yang cukup banyak digemari masyarakat kota Palu yang selalu menciptakan banyak inovasi terbaru. Keunggulan dari produk sabun mandi Shinzui yaitu sebagai satu-satunya produk sabun pemutih yang mengandung herba matsu oil ekstrak tumbuhan alami dari Jepang, dengan positioning tersebut sabun mandi Shinzui memilki potensi pangsa pasar yang cukup besar dipasaran.

Berdasarkan uraian di atas, maka keputusan pembelian dipengaruhi oleh beberapa hal. Untuk itu perlu diketahui melalui penelitian dengan tujuan untuk mengetahui:

1. Variabel kualitas produk yang terdiri dari kinerja (performance),fitur (features), kehandalan (reliability), daya tahan (durability), kesesuaian (conformance), estetika (esthetica), dan kualitas yang dirasakan (perceived quality) secara simultan berpengaruh siginifikan terhadap keputusan pembelian ulang sabun mandi merek Shinzui di Kota Palu.

2. Variabel kinerja (performance) secara parsial berpengaruh signifikan terhadap keputusan pembelian ulang sabun mandi merek Shinzui di Kota Palu.

3. Variabel fitur (features) secara parsial berpengaruh signifikan terhadap keputusan pembelian ulang sabun mandi merek Shinzui di Kota Palu.

4. Variabel kehandalan (reliability) secara parsial berepengaruh signifikan terhadap keputusan pembelian ulang sabun mandi merek Shinzui di Kota Palu.

5. Variabel daya tahan (durability) secara parsial berpengaruh signifikan terhadap keputusan pembelian ulang sabun mandi merek Shinzui di Kota Palu.

6. Variabel kesesuaian (conformance) secara parsial berpengaruh signifikan terhadap keputusan pembelian ulang sabun mandi merek Shinzui di Kota Palu.

7. Variabel estetika (esthetica) secara parsial berpengaruh signifikan terhadap keputusan pembelian ulang sabun mandi merek Shinzui di Kota Palu.

8. Variabel kualitas yang dirasakan (perceived quality) secara parsial berpengaruh signifikan terhadap keputusan pembelian ulang sabun mandi merek Shinzui di Kota Palu. 


\section{KAJIAN LITERATURE}

\section{Pengertian Pemasaran}

Menurut Kotler (1992) pemasaran atau marketing adalah kegiatan manusia yang diarahkan untuk memenuhi kebutuhan dan keinginan melalui proses pertukaran. Konsep yang paling mendasar dalam pemasaran yaitu kebutuhan manusia, dimana kebutuhan manusia (human need) adalah keadaan seperti perasaan kehilangan dalam diri seseorang. Kebutuhan manusia itu luas dan kompleks yang meliputi kebutuhan dasar, rasa aman, sosial, penghargaan dan aktualisasi diri. Sedangkan keinginan manusia (human want) adalah bentuk yang berasal dari kebutuhan manusia yang dibentuk oleh budaya dan pribadi seseorang.

Tujuan pemasaran menurut Sunyoto (2013) adalah membuat agar penjual berlebih-lebihan dan mengetahui serta memahami konsumen dengan baik sehingga produk atau pelayanan cocok dengan konsumen tersebut dan laku dengan sendirinya. Berkembangnya masyarakat maka keinginan anggota masyarakat berkembang pula. Dilain pihak para produsen mengambil langkah khusus untuk menggerakkan keinginan masyarakat terhadap produknya. Para produsen memproduksikan produknya sebagai semua pemuas dari salah satu atau lebih kebutuhan manusia.

Defenisi pemasaran yang lainnya menurut Stanton (1994) pemasaran adalah suatu sistem keseluruhan dari kegiatan usaha yang ditujukan untuk merencanakan, menentukan harga, mempromosikan, dan mendistribusikan barang dan jasa yang dapat memuskan kebutuhan kepada pembeli yang ada maupun pembeli potensial. Pemasaran (marketing) adalah mengidentifikasi dan memenuhi kebutuhan manusia dan sosial. Salah satu defenisi yang baik dan singkat dari pemasaran adalah memenuhi kebutuhan dengan cara yang menguntungkan (kotler dan keller, 2009).

\section{Manajemen Pemasaran}

Menurut Tjiptono (2002) manajemen pemasaran adalah proses perencanaan dan pelaksanaan konsepsi penentuan harga, promosi dan distribusi barang, jasa, dan gagasan untuk menciptakan pertukaran dengan kelompok sasaran yang memenuhi tujuan pelanggan dan oganisasi. Menurut Kotler dan Keller (2009) manajemen pemasaran adalah manajemen pemasaran sebagai seni dan ilmu memilih pasar sasaran dan meraih, mempertahankan, serta menumbuhkan pelanggan dengan menciptakan, mengantarkan dan mengkomunikasikan nilai pelanggan yang unggul. Assauri (2010) mengartikan manajemen pemasaran sebagai kegiatan penganalisaan, perencanaan, pelaksanaan dan pengendalian program-program yang dibuat untuk membentuk, membangun, dan memelihara keuntungan dari pertukaran melalui sasaran pasar guna mencapai tujuan organisasi (perusahaan) dalam jangka panjang.

\section{Perilaku Konsumen}

Swastha dan Handoko (2008) mengartikan bahwa perilaku konsumen sebagfai perilaku yang diperlihatkan konsumen dalam mencari, membeli, menggunakan, mengevaluasi, dan menghabiskan produk dan jasa yang mereka harapkan akan memuaskan kebutuhan mereka. Menurut Kotler dan Keller (2009) mendefenisikan perilaku konsumen sebagai studi tentang cara individu, kelompok an organisasi menyeleksi, membeli, menggunakan, dan memposisikan barang atau jasa, gagasan atau pengalaman yang memuasan kebutuhan dan keinginan mereka. Perilaku konsumen menurut Mangkunegara (2009) didefenisikan sebagai tindakan individu yang secara langsung terlibat dalam usaha memperoleh dan menggunakan barang-barang serta jasa ekonomis termasuk proses pengambilan keputusan yang mendahului dan menentukan tindakan-tindakan tersebut.

\section{Kualitas Produk}

Swastha dan Handoko (2008) mengartikan bahwa perilaku konsumen sebagfai perilaku yang diperlihatkan konsumen dalam mencari, membeli, menggunakan, mengevaluasi, dan menghabiskan produk dan jasa yang mereka harapkan akan memuaskan kebutuhan mereka. Kotler dan Keller (2009) mendefenisikan perilaku konsumen sebagai studi tentang cara individu, kelompok dan organisasi 
menyeleksi, membeli, menggunakan, dan memposisikan barang atau jasa, gagasan atau pengalaman yang memuasan kebutuhan dan keinginan mereka. Perilaku konsumen menurut Mangkunegara (2009) didefenisikan sebagai tindakan individu yang secara langsung terlibat dalam usaha memperoleh dan menggunakan barang-barang serta jasa ekonomis termasuk proses pengambilan keputusan yang mendahului dan menentukan tindakan-tindakan tersebut. Untuk memahaminya maka Garvin (1987) mengemukakan bahwa ada delapan dimensi kualitas produk yang terdiri dari:

1. Kinerja (Performance)

Berkaitan dengan aspek fungsional dari produk itu dan merupakan karakteristik utama yang dipertimbangkan pelanggan ketika ingin membeli suatu produk, yaitu meliputi Faster (lebih cepat) berkaitan dengan dimensi waktu yang menggambarkan kecepatan dan kemudahan atau bagaimana untuk memperoleh produk ini, dan aspek Cheaper (lebih murah) berkaitan dengan dimensi biaya yang menggambarkan angka atau ongkos dari suatu produk yang harus dibayarkan oleh pelanggan.

2. Fitur(Feature)

Merupakan aspek kedua dari performansi yang menambah fungsi dasar berkaitan dengan pilihanpilihan dan pengembangannya.

3. Kehandalan(Reliability)

Berkaitan dengan tingkat probabilitas atau kemungkinan suatu produk melaksanakan fungsinya secara berhasil dalam perode waktu tertentu, dengan demikian kehandalan merupakan karakteristik yang merefleksikan kemungkinan atau probabilitas tingkat keberhasilan dalam penggunaan produk itu.

4. Daya Tahan(Durability)

Merupakan ukuran masa pakai suatu produk, karakteristik ini berkaitan dengan daya tahan produk itu.

5. Kesesuaian(Conformance)

Berkaitan dengan tingkat kesesuaian produk terhadap spesifikasi yang telah ditetapkan sebelumnya berdasarkan keinginan pelanggan, konformansi merefleksikan derajat dimana krakteristik desain produk dan karakteristik operasi memenuhi standar yang telah ditetapkan, serta sering didefenisikan sebagai konformansi terhadap kebutuhan.

6. Kemudahan Perbaikan(Service Ability)

Merupakan karakteristik yang berkaitan dengan kecepatan, keramahan atau kesopanan, kompetensi, kemudahan serta akurasi dalam perbaikan.

7. Estetika (Esthetica)

Merupakan karakteristik yang bersifat subyektif sehingga berkaitan dengan pertimbangan pribadi dan refleksi dari referensi atau pilihan individual.Dengan demikian estetika dari suatu produk lebih banyak berkaitan dengan perasaan pribadi dan mencakup krakteristik tertentu.

8. Kulaitas Yang Dirasakan(Perceived Quality)

Bersifat subyektif berkaitan dengan perasaan pelanggan dalam mengkonsumsi produk.

\section{Keputusan Pembelian Ulang}

Menurut Kotler (1997) Pembelian Ulang merupakan salah satu perilaku setelah pembelian yang sebelumnya didasari dengan kepuasan. Jika pelanggan merasa puas untuk selanjutnya dia akan memperlihatkan peluang membeli yang lebih tinggi dalam kesempatan berikutnya. Selain itu, Menurut Simamora (2003) apabila seseorang sudah pernah melakukan pembelian terhadap suatu produk dan ia akan melakukan pembelian ulang terhadap produk tersebut maka perilaku yang akan mungkin ditunjukkan ada dua yaitu:

1) Pemecahan masalah berulang

Alasan melakukan pemecahan masalah dalam pembelian ulang disebabkan oleh beberapa kemungkinan: 
a) Konsumen tidak puas dengan produk sebelumnya, sehingga memilih alternatif lainnya.

b) Pembelian pertama sudah lama akibatnya saat ingin melakukan pembelian ulang produk sudah mengalami banyak perubahan.

2) Perilaku karena kebiasaan

Perilaku ini tampak pada seseorang yang membeli merek/produk yang sama berulang-ulang.

Perilaku tersebut dapat terjadi karena dua hal:

a) Pengaruh loyalitas, dimana orang tersebut loyal terhadap merek/produk tersebut.

b) Karena kemasan, dimana seseorang membeli produk/merek yang sama karena malas mengevaluasi alternatif-alternatif yang tersedia.

\section{Kerangka Pemikiran}

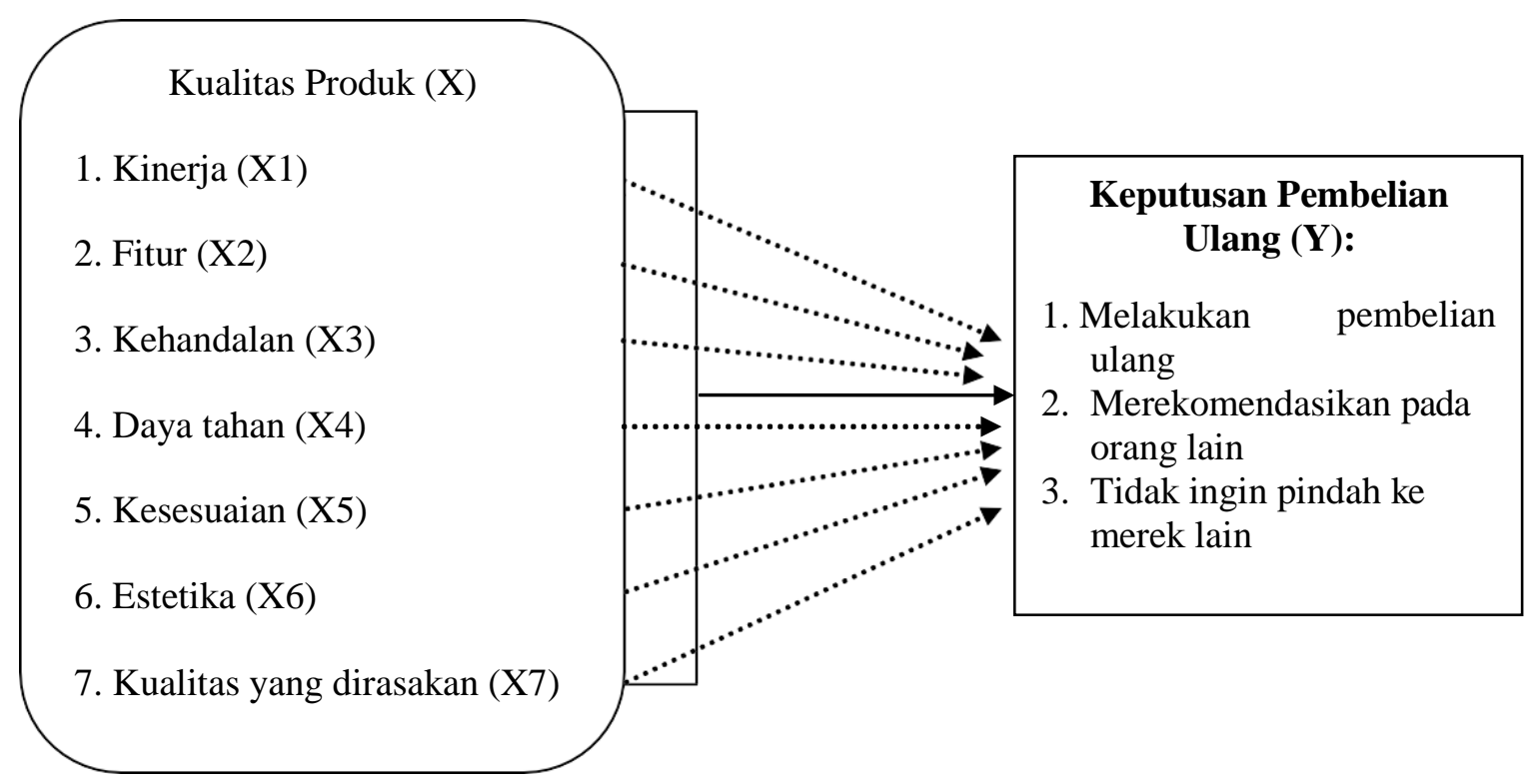

\section{Gambar 1 Kerangka pemikir}

Keterangan:

$$
\begin{aligned}
& \longrightarrow \text { Berpengaruh secara parsial } \\
& \longrightarrow \text { Berpengaruh secara simultan }
\end{aligned}
$$

\section{Hipotesis}

Berdasarkan teori dan kerangka berpikir diatas dapat disusun beberapa hipotesis sebagai berikut:

1. Bahwa kualitas produk yang terdiri dari kinerja (performance),fitur (features), kehandalan (reliability), daya tahan (durability),kesesuaian (conformance), estetika (esthetica), dan kualitas yang dirasakan (perceived quality) secara serempak berpengaruh signifikan terhadap keputusan pembelian ulang sabun mandi merek Shinzui di Kota Palu.

2. Kinerja (Performance) berpengaruh signifikan terhadap keputusan pembelian ulang sabun mandi merek Shinzui di Kota Palu.

3. Fitur (Features) berpengaruh signifikan terhadap keputusan pembelian ulang sabun mandi merek Shinzui di Kota Palu.

4. Kehandalan (Reliability) berpengaruh signifikan terhadap keputusan pembelian ulang sabun mandi merek Shinzui di Kota Palu. 
5. Daya tahan (Durability) berpengaruh signifikan terhadap keputusan pembelian ulang sabun mandi merek Shinzui di Kota Palu.

6. Kesesuaian (Conformance) berpengaruh signifikan terhadap keputusan pembelian ulang sabun mandimerek Shinzui di Kota Palu.

7. Estetika (Esthetica) berpengaruh signifikan terhadap keputusan pembelian ulang sabun mandi merek Shinzui di Kota Palu.

8. Kualitas yang dirasakan (Perceived quality) berpengaruh signifikan terhadap keputusan pembelian ulang sabun mandi merek Shinzui di Kota Palu.

\section{METODE PENELITIAN}

Jenis Penelitian ini adalah penelitian kuantitatif. Teknik pengumpulan data dan informasi yang dibutuhkan dalam penelitian ini yaitu menghimpun data dengan menggunakan beberapa bentuk metode pengumpulan data kuesioner, interview/wawancara, dan studi pustaka yang tidak mendalam, dan hasil penelitian cenderung untuk digeneralisasikan.

Populasi adalah wilayah generalisasi yang terdiri atas objek/subjek yang mempunyai kualitas dan karakteristik tertentu yang ditetapkan oleh peneliti untuk dipelajari dan kemudian ditarik kesimpulannya. Populasi dalam penelitian ini adalah masyarakat yang melakukan pembelian ulang sabun mandi merek Shinzui di Kota Palu. Adapun jumlah konsumen yang memutuskan melakukan pembelian ulang sabun mandi merek Shinzui tidak diketahui secara pasti. Teknik pengambilan sampel untuk menentukan sampel yang digunakan adalah teknik non probability sampling, yaitu purposive sampling. Purposive sampling adalah cara pengambilan sampel berdasarkan karakteristik tertentu, misalnya orang tersebut yang dianggap paling tahu tentang apa yang kita harapkan.

Penelitian ini merujuk kepada pendapat Roscoe (1982) yaitu Ukuran sampel yang layak dalam penelitian adalah antara $30 \mathrm{~s} / \mathrm{d}$ 500. jumlah anggota sampel minimal 10 kali dari jumlah variabel yang diteliti. Jumlah variabel Kualitas Produk dan Keputusan Pembelian Ulang yang diteliti sebanyak 8 variabel. Maka jumlah sampel yang ditentukan oleh peneliti adalah $10 \times 8=80$ responden dengan pertimbangan keterbatasan waktu, biaya, dan tenaga yang dimiliki oleh penulis.

Teknik analisis data yang dipergunakan dalam penelitian ini kuantitatif menggunakan regresi linier berganda.

\section{HASIL DAN PEMBAHASAN}

Analisis Regresi Berganda

Tabel 1

Ringkasan Hasil Uji Regresi Berganda

\begin{tabular}{|c|c|c|c|c|c|}
\hline \multicolumn{6}{|c|}{ Dependen Variabel Y = Pembelian Ulang } \\
\hline \multirow[t]{2}{*}{ Variabel Independen } & \multicolumn{2}{|c|}{ Unstandardized Coefficients } & \multirow{2}{*}{$\begin{array}{c}\text { Standardized } \\
\text { Coefficients } \\
\text { Beta }\end{array}$} & \multirow[t]{2}{*}{$\mathbf{T}$} & \multirow[t]{2}{*}{ Sig } \\
\hline & B & Standar Error & & & \\
\hline $\mathrm{C}=$ Costanta & .925 & .750 & & 1.234 & .221 \\
\hline Kinerja/ Performance $\left(\mathrm{X}_{1}\right)$ & .171 & .094 & .183 & 1.811 & .074 \\
\hline Fitur/ Features $\left(\mathrm{X}_{2}\right)$ & .265 & .077 & .371 & 3.462 & .001 \\
\hline Kehandalan/ Reliability $\left(\mathrm{X}_{3}\right)$ & .047 & .069 & .071 & 679 & .499 \\
\hline Daya Tahan/ Durability $\left(\mathrm{X}_{4}\right)$ & .036 & .088 & .043 & 405 & 687 \\
\hline Kesesuaian/ Conformance $\left(\mathrm{X}_{5}\right)$ & .010 & .083 & .013 & 118 & .906 \\
\hline Estetika/ Esthetica $\left(\mathrm{X}_{6}\right)$ & .009 & .095 & .011 & 100 & .921 \\
\hline $\begin{array}{l}\text { Kualitas Yang Dirasakan/ } \\
\text { Perceived Quality }\left(\mathrm{X}_{7}\right)\end{array}$ & .242 & .089 & .278 & 2.717 & .008 \\
\hline $\begin{array}{lll}\text { Multiple R } & =0.525 \\
\mathrm{R} \text { Square }\left(\mathrm{R}^{2}\right) & =0.276\end{array}$ & & Sig.F & $=0.001$ & & \\
\hline
\end{tabular}


Berdasarkan hasil tersebut apabila ditulis dalam bentuk standardized dari persamaan regresinya adalah sebagai berikut:

$Y=0.925+0.171 X_{1}+0.265 X_{2}+0.047 X_{3}+0.036 X_{4}+0.010 X_{5}+0.0 .09 X_{6}+0.242 X_{7}$

\section{Pembahasan}

\section{Pengujian Hipotesis Pertama (Uji F)}

Berdasarkan Tabel diatas, diperoleh nilai sig F yaitu 0.001, artinya nilai tersebut < jika dibandingkan dengan nilai yang diisyaratkan yaitu $\alpha \leq 0.05$. Dengan demikian dapat dinyatakan bahwa secara serempak variabel dari kinerja, fitur, kehandalan, daya tahan, kesesuaian, estetika, dan kualitas yang dirasakanberpengaruhsignifikan terhadap keputusan pembelian ulang sabun mandi Shinzui di Kota Palu.

\section{Pengujian Hipotesis (Hasil Uji t) \\ Hasil Pengujian Hipotesis Kedua $\left(\mathbf{X}_{1}\right)$}

Hasil pengujian seperti yang terlihat pada tabel rekapitulasi regresi linear berganda di atas, menunjukkan variabel kinerja memiliki nilai signifikansi 0.074 , artinya nilai tersebut $>$ dari taraf signifikan yang disyaratkan $\alpha \leq 0.05$. Dengan demikian maka dapat disimpulkan bahwa secara parsial produk berpengaruh tidak signifikan terhadap keputusan pembelian ulang sabun mandi Shinzui di Kota Palu. dengan nilai koefisien regresi sebesar 0.17.

\section{Hasil Pengujian Hipotesis Ketiga $\left(\mathbf{X}_{2}\right)$}

Hasil pengujian seperti yang terlihat pada tabel rekapitulasi regresi linear berganda di atas, menunjukkan variabel fitur memiliki nilai signifikansi 0.001 , artinya nilai tersebut $<$ dari taraf signifikansi yang disyaratkan $\alpha \leq 0.05$. Dengan demikian maka dapat disimpulkan bahwa secara parsial keistimewaan berpengaruh signifikan terhadap keputusan pembelian ulang sabun mandi Shinzui di Kota Palu, dengan nilai koefisien regresi sebesar 0.265.

\section{Hasil Pengujian Hipotesis Keempat $\left(\mathbf{X}_{3}\right)$}

Hasil pengujian seperti yang terlihat pada tabel rekapitulasi regresi linear berganda di atas, menunjukkan variabel Kehandalan memiliki nilai signifikansi 0.499 , artinya nilai tersebut $>$ dari taraf signifikansi yang disyaratkan $\alpha \leq 0.05$. Dengan demikian maka dapat disimpulkan bahwa secara parsial kehandalan berpengaruh tidak signifikan terhadap keputusan pembelian ulang sabun mandi Shinzui di Kota Palu, dengan nilai koefisien regresi sebesar 0.047.

\section{Hasil Pengujian Hipotesis Kelima $\left(\mathbf{X}_{4}\right)$}

Hasil pengujian seperti yang terlihat pada tabel rekapitulasi regresi linear berganda di atas, menunjukkan variabel Daya tahan memiliki nilai signifikansi 0.687 , artinya nilai tersebut $>$ dari taraf signifikansi yang disyaratkan $\alpha \leq 0.05$. Dengan demikian maka dapat disimpulkan bahwa secara parsial daya tahan berpengaruh tidak signifikan terhadap terhadap keputusan pembelian ulang sabun mandi Shinzui di Kota Palu, dengan nilai koefisien regresi sebesar 0.036.

\section{Hasil Pengujian Hipotesis Keenam $\left(\mathbf{X}_{5}\right)$}

Hasil pengujian seperti yang terlihat pada tabel rekapitulasi regresi linear berganda di atas, menunjukkan variabel kesesuaian memiliki nilai signifikansi 0.906 , artinya nilai tersebut $>$ dari taraf signifikansi yang disyaratkan $\alpha \leq 0.05$.Dengan demikian maka dapat disimpulkan bahwa secara parsial kesesuaian berpengaruh tidak signifikan terhadap keputusan pembelian ulang sabun mandi Shinzui di Kota Palu, dengan nilai koefisien regresi sebesar 0.010. 


\section{Hasil Pengujian Hipotesis Ketujuh $\left(\mathbf{X}_{6}\right)$}

Hasil pengujian seperti yang terlihat pada tabel rekapitulasi regresi linear berganda di atas, menunjukkan variabel estetika memiliki nilai signifikansi 0.921 , artinya nilai tersebut $>$ dari taraf signifikansi yang disyaratkan $\alpha \leq 0.05$. Dengan demikian maka dapat disimpulkan bahwa secara parsial Estetika berpengaruh tidak signifikan terhadap keputusan pembelian ulang sabun mandi Shinzui di Kota Palu, dengan nilai koefisien regresi sebesar 0.009.

\section{Hasil Pengujian Hipotesis Kedelapan $\left(\mathbf{X}_{7}\right)$}

Hasil pengujian seperti yang terlihat pada tabel rekapitulasi regresi linear berganda di atas, menunjukkan variabel kualitas yang dirasakan memiliki nilai signifikansi 0.008 , artinya nilai tersebut $<$ dari taraf signifikansi yang disyaratkan $\alpha \leq 0.05$ dengan demikian maka dapat disimpulkan bahwa secara parsial kualitas yang dirasakanberpengaruh signifikan terhadap keputusan pembelian ulang sabun mandi Shinzui di Kota Palu, dengan nilai koefisien regresi sebesar 0.242.

\section{Koefisien Determinasi $\left(\mathbf{R}^{2}\right)$}

Dari Tabel diatas juga dapat dilihat pengaruh hasil uji determinasi $R$ Square $\left(R^{2}\right)$ sebesar 0.276. Nilai tersebut dapat diartikan bahwa seluruh variabel bebas yakni kinerja, fitur, kehandalan, daya tahan, kesesuaian, estetika, dan kualitas yang dirasakan mempunyai kontribusi secara bersama-sama sebesar $27.6 \%$ terhadapvariabel terikat yaitu keputusan pembelian ulang. Sedangkan sisanya (100\%$27.6 \%=72.4 \%$ ), dipengaruhi oleh variabel lain yang tidak diteliti. Adapun tingkat keeratan hubungan antara variabel bebas yaitu kualitas produk terhadap variabel terikat atau keputusan pembelian ulang sabun mandi Shinzui di Kota Palu, dapat dilihat melalui nilai Multiple R sebesar 0.525 atau 52.5\%. Hasil tersebut menunjukkan bahwa secara keseluruhan variabel bebas berhubungan cukup erat terhadap variabel terikat.

\section{KESIMPULAN DAN SARAN}

\section{Kesimpulan}

Berdasarkan hasil penelitian yang ditemukan, maka didapatkan beberapa kesimpulan sebagai berikut:

1. Variabel kualitas produk yang terdiri dari kinerja (performance), fitur (features), kehandalan (reliability), daya tahan (durability), kesesuaian (conformance), estetika (esthetica), dan kualitas yang dirasakan (perceived quality) berpengaruh signifikan terhadap keputusan pembelian ulang sabun mandi merek Shinzui di Kota Palu.

2. Variabel kinerja (performance), berpengaruh tidak signifikan terhadap keputusan pembelian ulang sabun mandi merek Shinzui di Kota Palu.

3. Variabel fitur (features), berpengaruh signifikan terhadap keputusan pembelian ulang sabun mandi merek Shinzui di Kota Palu.

4. Variabel kehandalan (reliability), berpengaruh tidak signifikan terhadap keputusan pembelian ulang sabun mandi merek Shinzui di Kota Palu.

5. Variabel daya tahan (durability), berpengaruh tidak signifikan terhadap keputusan pembelian ulang sabun mandi merek Shinzui di Kota Palu.

6. Variabel kesesuaian (conformance), berpengaruh tidak signifikan terhadap keputusan pembelian ulang sabun mandi merek Shinzui di Kota Palu.

7. Variabel estetika (esthetica), berpengaruh tidak signifikan terhadap keputusan pembelian ulang sabun mandi merek Shinzui di Kota Palu.

8. Variabel Kualitas Yang dirasakan (perceived quality), berpengaruh signifikan terhadap keputusan pembelian ulang sabun mandi merek Shinzui di Kota Palu. 


\section{Saran}

Berdasarkan hasil kesimpulan yang didapatkan, maka disarankan beberapa hal dari hasil penelitian ini, yaitu sebagai berikut:

1. Hasil analisis menunjukkan dari variabel-variabel Kinerja (performance), fitur (features), kehandalan (reliability), daya tahan (durability), kesesuaian (conformance), estetika (esthetica), dan kualitas yang dirasakan (perceived quality), secara parsial yang memiliki signifikansi terhadap proses keputusan pembelian ulang (Y) hanyalah variabel fitur (features), dan kualitas yang dirasakan (perceived quality), Sehingga pihak perusahaan diharapkan untuk mampu meningkatkan signifikansi lima variabel lain yang secara parsial belum memiliki signifikansi pengaruh terhadap keputusan pembelian ulang pada sabun mandi merek Shinzui.

2. Hasil analisis juga menunjukkan bahwa variabel fitur (features) mempunyai pengaruh yang dominan terhadap proses keputusan pembelian ulang dibandingkan dengan limavariabel lainnya, oleh karena itu perusahaan PT. Bina Karya Prima disarankan agar lebih mempertahankan bahkan meningkatkan fiturnya. Dengan cara menambah jenis yang lebih bervariasi, menambah aroma yang bervariasi, serta lebih menghasilkan busa yang banyak.

3. Hasil analisis juga menunjukkan bahwa variabel kualitas yang dirasakan (perceived quality) mempunyai pengaruh yang dominan terhadap proses keputusan pembelian ulang dibandingkan dengan lima variabel lainnya, oleh karena itu perusahaan PT. Bina Karya Prima disarankan agar lebih meningkatkan kualitas dengan cara menambah tingkat kualitas yang sehingga lebih diakui masyarakat, lebih mampu bersaing dengan merek lain, dan mempertahankan bahan alami yang lebih berkualitas.

4. Bagi peneliti selanjutnya, diharapkan penelitian ini dapat dijadikan bahan acuan dan perbandingan dalam melakukan penelitian serupa di masa yang akan datang, khususnya tentang kualitas produk dan pengaruhnya terhadap keputusan pembelian ulang.

\section{REFERENSI}

Assauri. (2010). Manajemen Pemasaran (sepuluh). Jakarta: PT. Rajagravindo.

Daryanto. (2014). Konsumen dan pelayanan prima. Malang: Gravamedia.

Garvin, David. (1987). Managing Quality. New York: The free press.

Kotler, Philip. (1997). Marketing Jild 2. Jakarta: Erlangga.

Kotler. Philip. (2009). Manajemen Pemasaran: Anlaisis, Perencanaan, Implementasi, Dan

Pengendalian. Edisike 2. Jakarta: Erlangga.

Kotlerbdan Keller. (2009). Manajemen Pemasaran Jilid 1. Edisike 13, Jakarta: Erlangga.

Mangkunegara, AA. Anwar Prabu. (2009). Manajemen Sumber Daya Manusia. Bandung: PT Remaja Rosdakarya.

Nabhan dan Kresnaini. (2005). Faktor-Faktor Yang Berpengaruh Terhadap Keputusan Konsumen Dalam Melakukan Pembelian Pada Rumah Makan Di Kota Batu. Jurnal Ekonomi Dan Manajemen, Vol.6, No.3.

Roscoe. (1982). Research Methods For Business. New York: McGraw Hill.

Simamora, Bilson. (2003). Riset Pemasaran dan Perilaku Konsumen. Jakarta: Gramedia Pustaka Utama.

Sunyoto, Danang. (2013). Teori Kuosioner\&Analisis Data Untuk Pemasaran dan Perilaku Konsumen.

Cetakan 1, Yogyakarta: Penerbit Graha Ilmu.

Sugiyono. (2013). Metode Penelitian Administrasi Dilengkapi Dengan Metode $R \&$ D. Bandung: Alfabeta.

Stanton, William J. (2004). Prinsip-Prinsip Pemasaran. Jakarta: Erlangga.

Swastha, Basu DH., \& Handoko, T Hani. (2008). Manajemen Pemasaran: Analisis Perilaku

Konsumen.Edisi Pertama Cetakan Keempat, Yogyakarta: BPFE. 
Hartati

Tjiptono, F. (2002). Strategi Pemasaran. Yogyakarta: Andi Offset 